\title{
Study on the Teaching of Fundamentals of Manufacturing Technology in Independent College

\author{
- Take the College of Arts \& Science of Jianghan University as Example
}

\author{
Li Congquan \\ Department of electromechanics and Architecture \\ College of Arts \& Science of Jianghan University \\ Wuhan, China \\ licongquan@sina.com
}

\begin{abstract}
The teaching of manufacturing technology has been researched according to the situation of independent college. That be strict with students and concise key contents could bring good effect in class. Mechanical processing video can add engineering background .Reform the examination can reduce examination malpractice, can promote the ability of operation, and can deepen the understanding of the text. The network technology does help to teach and communicate conveniently. Encourage students to participate professional contest brings professional atmosphere. The teaching mode cultivates the students' independent thinking and practical ability. The effects play a good foundation for professional study.
\end{abstract}

Keywords- independent college, mechanical manufacturing, teaching, practical ability

\section{INTRODUCTION}

Manufacturing technology is a required course in the major of Mechanical Manufacture and Automation in many independent colleges. The course is an integrated course covering 4 aspects. The 4 aspects are as follows: the mechanical manufacturing technology, principle of metal cutting and cutting tool, machine tool and jigs. This course is designed to enable students to master the methods of processing, process planning, analyzing quality problems, designing and repairing equipment. The integrated course is based on the theory of mathematics, mechanics, and materials science, etc. So it has a higher theoretical level.

Simultaneously, it gets involve in machine tool, fixture, cutting tool and process procedures, which is extremely practically.

\section{PROBLEMS IN TEACHING}

Such problems lie in the teaching of manufacturing technology in independent college.

\section{A. Weak in practice}

Some conventional equipment, such as lathe, shaver, milling, grinding and boring, etc, shall be offered in the experiments in the course. However, independent college, which is of a short history, has insufficient hardware devices for experiments. ${ }^{[1][2]}$ Experimental teaching often relies on devices in hosting college. Arrangement schedules can not

\author{
Fan Chaoyi
}

Department of electromechanics and Architecture College of Arts \& Science of Jianghan University Wuhan, China

get up with the teaching schedules. Study is mainly in theoretical teaching. The productive practice is predominantly visiting. Too many students, noise and scattered processing brings less effectiveness. Productive practice is much poorer.

\section{B. Insufficient motivations}

Most students in independent colleges are only child in the family. Their living conditions are superior. But they are not well-motivated. They have much more self-consciousness in their campus lives, but they are often dependent on teachers in studies. ${ }^{[3]}$ Many students are not active in their studies. For example, they often can not hand in their homework in time, or often are late for class. Playing cell-phone in class is frequently shown. Complex formula, specific structure and rigid words in manufacturing technology are flavorless for them.

\section{The not-well designed examination}

The test-oriented education still affects the teaching activities. ${ }^{[4]}$ Independent college students are not good at taking exam. Relying on the designated scope for exam, spending one or two weeks' preparation for test, the make-up examination leads to bad habits in learning. ${ }^{[5]}$ These bring the insufficient practicing capability of students.

\section{MODEL FRAMEWORK}

Considering the conventional teaching for independent college students, the teaching mode of manufacturing technology shall be established. The mode is made up of two parts: teaching in class and extracurricular activities.

Teaching in class consists of classroom lecturing, professional practice, test and supplement. Extracurricular activities include network learning, extracurricular teaching and student contest. Model framework is shown in table I .

TABLE I . MODEL FRAMEWORK

\begin{tabular}{c|c}
\hline Teaching in class & extracurricular activity \\
\hline
\end{tabular}




\begin{tabular}{l|l}
\hline $\begin{array}{l}\text { 1. Classroom lecturing } \\
\text { 2.professional practice }\end{array}$ & $\begin{array}{l}\text { 1.network learning } \\
\text { 3. test }\end{array}$ \\
2. Supplement & \begin{tabular}{l} 
3.Student contest \\
\hline
\end{tabular} \\
\hline
\end{tabular}

\section{IMPLEMENTATION AND RESULTS}

\section{A.. Teaching in class}

\section{(a) Classroom lecturing}

According to survey, the students are not interested in their majoring courses among independent college students, such as sleeping, playing mobile phone in class. The reason is that most students think the course is too difficult for them to understand. Therefore, encouraging students to overcome the difficulties is an important task in independent colleges. There are abundant contents in machinery manufacturing. Some of them are just required to be simply understood. ${ }^{[6]}$ Focus shall be clarified before giving lectures. Basic concepts, principles shall be clearly conveyed to students. Difficult points, such as the structure of the machine tool, would be introduced briefly. Students who may dive into the process within his capacity can take further studies. Encouraging students to raise questions, and the teacher should patiently answer. Roll-call in class, handing in homework in time shall also be conducted. Those who do homework well shall be promptly recommended and encouraged to make further progresses. Students shall be penalized for mistakes. The approaches for teaching involve blackboard-writing, doing exercises, question, discussing and mistake analyzing, etc.Introducing new processing technology and the advanced technology innovation can broaden students' views. Collecting students' ideas, improving teaching methods and making friends with them can motivate students' initiative.

\section{(b) Professional practice}

In the course, students are required to take experiments. Before the experiment, teacher shall ask students to read requirements for the task seriously. So the purpose and the experimental steps could be known. Students shall be required to operate, observe and record carefully.
Curriculum design is another practice. There are two forms. One more capable student is asked to take a separate task, and 2-3 less capable students are asked to complete one corporate task. Tasks involving computers shall be asked one task for one student and the title shall be previewed by the mentor. The quality of curriculum design in 2011 was improved obviously, and the writing norms were also significantly improved. There are two designs of jigs simulated the work process with the help of computers.

(c) Test

Testing is a basic approach to assess the teaching and can guide students in learning. Before 2008, testing with references is widely employed. It is too easy to testify the teaching results. But for engineers, they often consult manual to solve problems in manufacturing. In 2009, the combination of examination with references and without references was introduced. Basic concepts and principles are tested without references, and the applied testing is with references. The testing score makes up $70 \%$ of the final, daily performance is of $30 \%$.Test reforming promotes the learning of the course. In 2012, small production performance is included in the final score. Students who make a perfect tool model may obtain 3 points, and who make a perfect jig model may obtain 15 points. Test with references accounts for $50 \%$ proportions, and test without references accounts for $50 \%$ proportions. The course grade is made up of three parts: testing scores accounts for $60 \%$, class performance $20 \%$, and extracurricular work $20 \%$.The reform increases pressure in the study, enables extracurricular reading and manipulative capability. Changes of examination refresh teaching and learning.

\section{(d) Supplement}

\section{1 ) Supply theory}

The admission score of students in independent college in Hubei province is 96-106 less than its hosting college. ${ }^{[7]}$ Students were not of good foundations in this course in middle school. There are many difficulties encountered in professional courses in college. Basic knowledge shall be supplied to manufacturing technology. Supplements are shown in Table II.

TABLE II. SUPPLY THEORY

\begin{tabular}{l|l|l|l|l}
\hline Section: & cutting tool & Mechanical processing & Process procedures & Quality management \\
\hline $\begin{array}{l}\text { Supply } \\
\text { content }\end{array}$ & Projection knowledge & $\begin{array}{c}\text { Force-operation,quenching,tempering, } \\
\text { Quenching and tempering }\end{array}$ & reading processing procedure & Tolerance fit and \\
technical & & \\
\hline
\end{tabular}

By adding the basic knowledge, the course can be easily understood. A survey displayed that students supplied the basic knowledge clearly differ from those without it. 20\% of understanding can be achieved with the latter while more $30 \%$ the former.

\section{2) Supplying practice}

Without the background of engineering, students have difficulties in understanding the process of manufacturing, cutting tool and machine tool fixture. Collecting engineering practice information can be an effective way to strengthen the weak practicing capability, including turning, milling, planning, grinding and other processing. Partly cutting tool 
showed in figure $1 .^{[8]}$

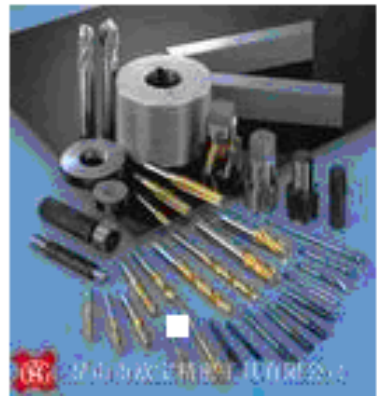

Figure 1. Cutting tool

Video showed the practice can attract attention from students and deepen their understanding. The survey showed the percentage of chatting and playing cell-phone without video can reach $25 \%$. Teaching with video can attract $90 \%$ students in class. The video of mechanical processing offers pleasure in learning and raises their interests. Scenes showed in figure 2.

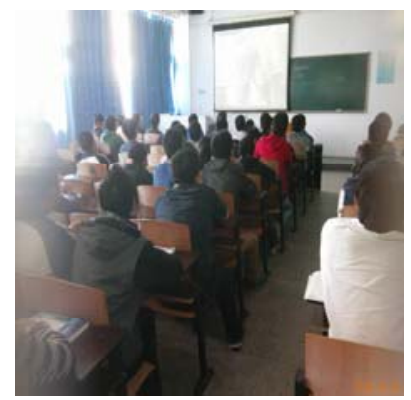

Figure 2 .Watch the video

\section{B. Extracurricular activities}

\section{(a) Network learning}

Happy is an emotional to be a base for further learning. Internet is a necessary part in modern life. Independent college students like surfing on the internet. Online learning is a complement for classroom learning. With the help of network, asking, answering, discussing, guiding, surveying and resources sharing can be employed. There is one-to-one communication between teachers and students upon the network technology. Students can directly communicate with their teachers.

\section{(b) Extracurricular works}

Extracurricular works shall follow syllabus of manufacturing technology. The topic shall be feasible, including tool model, fixture model, and device model. The purpose of extracurricular works is to consolidate knowledge in class, and to develop the practicing ability. In 2011, there was a try to encourage some students, who has spare capacity to engage in extracurricular works. Some students made tools and fixtures with the help of computer simulation technique. Experiment proved that extracurricular works did not increase the burden of learning, but attract more other students asks to make a model. In 2012, the number of students involved in extracurricular works reached 90, 110 tool models and 3 fixture models were made. Some students made some models prior to learning, which showed that the activity inspired students to learn independently. Encouraging students to observe the mechanical parts carefully, analyze its structure, think about the process, and try to write it down, which can also affect the students' extracurricular learning.

\section{(c) Student contest}

Practice is the source of innovation. The learning of manufacturing technology shall be combined with application. In this way, designing good manufacture parts can be effective. Students were organized to participate in professional contests every year. In this way students can better apply theories in manufacturing technology to practice, which brings student closer to engineering application. In 2011, 25 students applied to take part in the National Collegiate Digital Design Contest. 25 students contested in college firstly. The contests mobilized the enthusiasm, and widen the students' view. Partial award-winning works in table III.

TABle III. PARTIAL AWARD-WinNING WORK

\begin{tabular}{l|l|l|l}
\hline $\begin{array}{c}\text { name of the } \\
\text { contest }\end{array}$ & $\begin{array}{l}\text { The mechanical design contest of } \\
\text { Hubei Province College In 2010 }\end{array}$ & $\begin{array}{l}\text { The mechanical design } \\
\text { contest of Hubei Province } \\
\text { College In 2012 }\end{array}$ & $\begin{array}{l}\text { National University Digital } \\
\text { design competition in } 2012\end{array}$ \\
\hline Title & $\begin{array}{l}\text { The Design of Earthquake building } \\
\text { structure }\end{array}$ & Rope machine & Design of mechanical dog \\
\hline rating & third prize & third prize & second prize \\
\hline
\end{tabular}

\section{SUMMARIES}

With 5 years practice, a teaching mode of manufacturing technology has evolved, and good results are achieved. Passive attitude has been turned to aggressive in this course. A harmonious atmosphere has been established between teachers and students. The teaching satisfaction of the course increased year by year. In 2009, third teaching prize in our college is rewarded to the search. In 2012 master of the search obtained the right to choose teaching achievement awards of universities in Hubei Province. Orientation for improving the teaching is to compile good text book of 
manufacturing technology for independent colleges. The work has been carried out with Huazhong University of Science and Technology Wenhua College. The construction of laboratories in independent colleges shall be of priority, and also be open-laboratories available for students.

\section{ACKNOWLEDGMENT}

This research was supported by the Twelfth Five-Year Plan of Hubei Province Educational Science (Grant No. 2011B350), and the Teaching and Research Project of Wuhan Education Bureau (Grant No.2012-2-2011138), and the Teaching and Research Project of College of Arts \& Science of Jianghan University. All supports are gratefully acknowledged. In addition, I must offer my heartfelt thanks to the judges and staff of ICETMS 2013.

\section{REFERENCES}

[1].Xu chunking yang huibin huang yongjun. Reformation of the construction and management in Independent college laboratory[J].Contemporary Education BBS, 2008(10):114-116.

[2].Liu Kun .Exploration for the teaching method of"communication principle"in independent college [J] Electronic Design Engineering. 2011(16):118-120.

[3].Wang yu. Study on the Students' Initiative in independent college [J]. Data of Culture and Education, 2010(32):164-167.

[4].Wang shouwan. People who study in exam-oriented education can not win the Nobel Prize [J]. Innovation science and technology, 2010(32):164-167.

[5].Zhou Miao, Lu yipping. Advantages of process assessment [J]. Chinese Education reform Herald, 2012(04):148-149.

[6].Academic administration of Shanghai University. Teach students How to self-study [M].Shanghai university press 2000(08) : preface1-2

[7]. http://edu.hbksw.gkcx.eol.cn/

[8]. www.baiduimage\&ct.con. 